DOI 10.7251/SCMED1802141V

UDC 615.099:632.954 COBISS.RS-ID 7839512

\title{
Acute Poisoning with Herbicide Glyphosate
}

\begin{abstract}
Glyphosate is the most common used organophosphorus herbicide which most probably inhibits oxidative phosphorylation without leading to the inhibition of esterases. Glyphosate poisoning is mostly the consequence of the synergistic effect of an active substance and surfactant. There is a case of 42-year-old patient who worked on weed spraying with glyphosate, with hand sprinkler. Symptoms of the acute poisoning such as weakness, sweating, nausea, vomiting and stomach ache were visible right after the working period. With biochemical analysis increased activity of the enzymes AST, ALT and y-GT were diagnosed and sanated after aborting an expositions in the period of six months and treatment. In this shown case poisoning was caused during applying herbicides without proper handling with the herbicide and also because of non-compliance of measures in safety and health at work. It is very clear that this is a case of acute poisoning with pesticides which ended with no consequences and was declared as work injury.
\end{abstract}

Key words: glyphosate, acute poisoning, enzymes, safety and health

(Scr Med 2018:49:141-144)

\section{Milidrag Vukotić, Vesna Paleksić, Slaviša Narićc}

${ }^{1}$ Institute for Occupational Health and Sports of Republic of Srpska Banja Luka

${ }^{2}$ Faculty of Medicine, University of Banja Luka, Banja Luka, Republic of Srpska, Bosnia and Herzegovina

\section{Corresponding author:}

Milidrag Vukotić,

e-mail:

zavod-mris@blic.net

Manuscript received:

May 21 $1^{\text {st }}, 2018$

Manuscript accepted:

November $19^{\text {th }}, 2018$

\section{Introduction}

Glyphosate (N-phosphonomethylglycine) is a nonselective (total) organophosphorus herbicide, with wide spectrum of action to suppress undesirable vegetation on agricultural and non-agricultural soil and is one of the most widely used herbicides worldwide. It is considered to be a minimum toxic for humans. ${ }^{1}$ It does not lead to esterase inhibition, it is considered that the mechanism of glyphosate toxicity in mammals is to prevent oxidative phosphorylation. ${ }^{2}$ Acute oral lethal dose LD50 for rats is $>4320 \mathrm{mg} / \mathrm{kg}$, dermal LD50 is $>2 \mathrm{~g} / \mathrm{kg}$ and the inhaled lethal concentration 50 is $>4.43 \mathrm{mg} / \mathrm{l} .^{3}$ After oral ingestion of glyphosate $30-36 \%$ is absorbed, maximum concentrations occur in tissues 6 hours after poisoning, undergoes with small metabolic processes and excretes largely unchanged in feces and secondary to the urine. Gastrointestinal symptoms are most common manifestations after oral poisoning. It exacerbates gastrointestinal tract erosion, difficulty swallowing and gastrointestinal bleeding. Eye and skin irritation occurs occasionally when exposured through the skin. Ingestion of the fog when spraying can cause irritation in the mouth, nose, eyes and throat. Severe poisoning causes dehydration, hypotension, pneumonitis, oliguria, changes in consciousness levels, hepatic dysfunction, acidosis, hypercalemia and dysrhythmia. ${ }^{4,5}$ Patients developing acute renal failure, hypercalemia, pulmonary edema and metabolic acidosis are more likely to die. ${ }^{6}$ However, in commercial products , glyphosate is dissolved in surfactants, substances added to herbicides to enhance their resorption and which can significantly contribute to the toxicity of the products. ${ }^{7}$ Most commonly, 
isopropylammonium (IPA) and polyoxyethyleneamine (POEA) are used. This is particularly true of glyphosatebased preparations, which have proven to be more toxic than individual components. ${ }^{8,9}$ Therefore, it is more appropriate in the poisoning of these formulations as a toxic agent to name glyphosate surfactant than glyphosate. The acute toxicity of herbicides containing glyphosate and surfactant was first described in the medical literature by Japanese authors who published a series of 56 cases of self-destruction, including nine deaths..$^{10}$ By their estimates, the lethal dose of the peroral injected preparation was about $200 \mathrm{~mL}$. Considering the low acute toxicity of glyphosate, this group of authors argued that polyoxyethyleneamine toxicity (POEA) was a surfactant in most products. ${ }^{10}$ Based on published cases, the symptoms and signs of poisoning containing glyphosate and surfactant preparations included abdominal pain, vomiting, stagnant changes in the lungs, pneumonia, acute lung injury, somnolence-to-coma awareness disorder, haemolysis, hypotension, renal insufficiency, shock, erosion of the gastrointestinal tract and larinx damage. ${ }^{11,12}$

There is no antidote for glyphosate, and treatment is both supportive and symptomatic. The basis for systemic toxicity is decontamination and aggressive symptomatic therapy. Gastric emptying or active coal may be applied to patients $<1 \mathrm{~h}$ after ingestion and have no severe irritation or erosion.

\section{The aim}

The aim of this work is to point out the clinical picture of acute glyphosate poisoning and the importance of preventative measures and measures of safety and health at work.

\section{Case report}

There is shown a case of a 42-year-old male, employed as a cleaner of the streets and green areas. He has worked for 9 months until this case occurred. Lowskilled worker, finished elementary school. According to anamnestic data, alcohol consumes "moderately". On May 27th, he worked on spraying the weeds on green areas beside the public roads, with the manually sprayer worn on his back. Spraying mixture was made by himself by diluting the herbicide glyphosate from the plastic bottle with water. He usually used a work suit, shoes, and had gloves available. He did not have protective glasses, face visor, and mask. He worked from 08 to 14 o'clock in the warm and sunny weather, with no significant wind. Together with him were two more experienced workers who had no symptoms of poisoning. During the work he had a half-hour meal break. The meal was eaten at the workplace without hand washing. After working hours he felt the first problems in the form of exhaustion, weakness in his hands and feet, nausea, anxiety, and appetite loss. The next day, besides the aforementioned problems and vomiting in the morning, he went to work and continued to work the same job at another location from 08:00 to 13:30 when he stopped because he felt the general weakness, could not stand on his feet, vomiting, stomach pain, headache, sweating, and reports to Emergency Medical Assistance when a diagnosis is made: T47 (poisoning by means primarily acting on the gastrointestinal tract - Intoxicatio instrumentis systema gastrointenstinale primum afficientibus); T60 (Toxic effect of pesticides - Effectus pesticidorum toxicus) and Ao5 (Other food poisoning caused by bacteria Intoxicationes alimentariae bacteriales aliae). From the Emergency medical help he is sent to the Intern Clinic. In the admissions of the Internal Clinic was examined, not hospitalized, given symptomatic therapy and diagnosed: Intoxicatio cum glyphosat susp. It was appointed for a control with certain biochemical laboratory findings. No consultation of the medicine work was requested.

A check-up of the gastroenterologist at the International Clinic was carried out the following day, on the basis of clinical examination and biochemical findings suggesting an increase in enzymatic activity: aspartate - aminotransferase (AST) 125U / L, alanine aminotransferase (ALT) 130U / L, gamma glutamyl transferase ( $\gamma$-GT) $926 \mathrm{U} / \mathrm{L}$, and urinary system infection, diagnoses: Laesio hepatis. Infectio tr. urinarii. Ultrasound examination (UZV) diagnosed enlarged liver.

The next gastroenterologist's check on June 11th of the same year, reported a slight decrease in enzymatic activity. In biochemical findings of the 18th of the same year, enzyme findings related to liver function improved. He was on a medical examination on July 4th the same year, 37 days after the scene. In the medicine of work it was noted that acute poisoning was performed with glyphosphate, a herbicide from the group of organophosphorus pesticides. The assumption is that the path of entry was the digestive (per os) and respiratory system. The patient was monitored, the values of the enzyme were normalized until September, except $\gamma$-GT. At the beginning of November of the same year, all findings were normalized,liver growth was sanated and the patient is returned to work.

\section{Discussion}

According to the World Health Organization (WHO) and the Food and Agriculture Organization (FAO), as well as some authors, early symptoms of glyphosate poisoning include vomiting, diarrhea, and other symptoms similar 
of flu. ${ }^{4}$ Poisoning may occur with absorption through the skin or through the mucous membrane. The individual may have rash or itching, redness, where direct skin contact has occurred. If swallowed, poisoning can mimic food poisoning and cause stomach cramps and possible throat irritation.4 Authors from Serbia described severe poisoning, most likely with surfactant, with neurological sequelae and lethal outcome. ${ }^{5,13}$ The clinical picture of the case described corresponds to the known and described symptom of the Glyphosate poisoning. In the case of the presented patient, the most significant manifestations of poisoning were the increase in enzyme activities of AST, ALT and $\gamma$-GT. Increased liver enzymes and liver damage, while experimental mice poisoned with glyphosate were alleged by Egyptian authors. ${ }^{14}$ Gastrointestinal disorders and liver injury, as well as renal disease, are also cited by other authors. ${ }^{4}$

By inspecting the health card, there is no evidence of habitual consumption of alcohol, or any other means of dependence or liver damage of another etiology, as confirmed by laboratory findings (hepatitis markers). The worker was temporarily unable to work until the clinical and liver enzyme finds were repaired, about 6 months when he returned to work. It has been established in the medical profession that this is not a professional illness, but a work injury.

The following factors have also been noted that have had a significant impact on the aforementioned event and resulted in acute poisoning: A workplace was not identified as a workplace with an increased risk, the worker was not trained to perform work safely and was not educated about the harmful effects of chemical substances used on the job, nor on the protection measures. When preparing the substance for the application, no measures for safe and healthy work, as well as during the application itself, are respected. Workers are not prohibited from consuming food and beverages during work, do not have to wash their hands for eating during meals during breaks, nor are they educated about the importance of personal hygiene in prevention, nor have they been provided with adequate personal protective equipment. No previous review was performed and no selection of workers for this job was performed according to health conditions.

\section{Conclusion}

In the case described, poisoning occurred during the application of the herbicide due to improper handling of the herbicide and non-compliance with safety and health at work. From the presented case it is apparent that poisoning with glyphosate pesticide has caused general weakness, headache, sweating, stomach pain, nausea, vomiting and liver damage, which has been remedied for 6 months without any consequences and is perceived as a work injury.

\section{References}

1. U.S. EPA. (1993) EPA R.E.D Facts: Glyphosate. Available from: http://www.epa.gov/pesticides/reregistration/RE Ds/factsheets/o178fact.pdf

2. Hietanen E, Linnainmaa K, Vainio H. Effects of phenoxyherbicides and glyphosate on the hepatic and intestinal biotransformation activities in the rat. Acta Pharmacol Toxicol (Copenh) 1983;53(2):103-12.

3. Cox C. Glyphosate. Part 1: Toxycology. J Pestic Reform 1995;15(3):14-20.

4. Bradberry SM, Proudfoot AT, Vale JA. Glyphosate poisoning. Toxicol Rev 2004; 23(3):159-67.

5. Potrebić O, Jović-Stošić J, Vučinić S, Tadić J, Radulac M. Akutno trovanje glifosat-surfaktantom sa neurološkim sekvelama i letalnim ishodom. Vojnosanit Pregl 2009; 66(9):758-62.

6. Lee HL, Chen KW, Chi CH, Huang JJ, Tsai LM. Clinical presentations and prognostic factors of a glyphosatesurfactant herbicide intoxication: a review of 131 cases. Acad Emerg Med 2000;7(8):906-10.

7. Talbot AR, Shiaw MH, Huang JS, Yang SF, Goo TS, Wang $\mathrm{SH}$, et al. Acute poisoning with a glyphosate-surfactant herbicide ('Roundup'): a review of 93 cases. Hum Exp Toxicol 1991;10(1):1-8.

8. Martinez TT, Long WC, Hiller R. Comparison of the toxicology of the herbicide roundup by oral and pulmonary routes of exposure. Proc West Pharmacol Soc 1990; 33:193-7.

9. Martinez TT, Brown K. Oral and pulmonary toxicology of the surfactant used in roundup herbicide. Proc West Pharmacol Soc 1991;34:43-6.

10. Sawada Y, Nagai Y, Ueyama M, Yamamoto I. Probable toxicity of surface-active agent in commercial herbicide containing glyphosate. Lancet 1988;1(8580):299.

11. Lee CH, Shih CP, Hsu KH, Hung DZ, Lin CC. The early prognostic factors of glyphosate-surfactant intoxication. Am J Emerg Med 2008;26(3):275-81.

12. Stella J, Ryan M. Glyphosate herbicide formulation: a potentially lethal ingestion. Emerg Med Australas 2004;16(3):235-9.

13. Lilić M, Dimitrov D, Zlatković M. Akutno trovanje glifosat surfaktantom-prikaz slučaja. MD-Medical Data 2015;7(3):245-7.

14. Youness ER, Agha FE, El-Toukhy SE, El-Naggar SMM, Selim AAI, Ibrahim AMM. The protective effect of orange juice on glyphosate toxicity in adult male mice. $\mathrm{J}$ Chem Pharm Res 2016;8(3):13-28. 


\section{Akutno trovanje glifosatom}

\section{SAŽETAK}

Uvod: Glifosat ja najčešće korišćeni organofosforni herbicid, koji ne dovodi do inhibicije esteraza, već najvjerovatnije onemogućava oksidativnu fosforilaciju. Trovanje glifosatom je najčešće posljedica sinergičnog dejstva aktivne materije i surfaktanta. Prikazan je slučaj pacijenta starog 42 godine koji je radio na prskanju korova glifosatom, ručnom prskalicom. Simptomi akutnog trovanja su se ispoljili neposredno nakon završetka radnog dana u vidu slabosti, znojenja, muke, povraćanja i bolova u stomaku. Biohemijskim nalazima utvrđene su povećane aktivnosti enzima AST, ALT i y- GT koje su se sanirale nakon prekida ekspozicije u trajanju od 6 mjeseci i liječenja. U prikazanom slučaju do trovanja je došlo prilikom primjene herbicida usljed nepravilnog rukovanja herbicidom i zbog nepridržavanja mjera bezbjednosti i zdravlja na radu. Iz prikazanog slučaja je očigledno da se radilo o akutnom trovanju pesticidom, koje se završilo bez posljedica, a koje je shvaćeno kao povreda na radu.

Ključne riječi: glifosat, akutno trovanje, enzimi, bezbjednost i zdravlje. 